\title{
Entrapment of a phage cocktail and cinnamaldehyde on sodium alginate emulsion-based films to fight food contamination by Escherichia coli and Salmonella Enteritidis
}

\author{
Diana Alves $^{\mathrm{a}}$, Miguel A. Cerqueira ${ }^{\mathrm{b}}$, Lorenzo M. Pastrana ${ }^{\mathrm{b}}$, Sanna Sillankorva ${ }^{\mathrm{a}, \mathrm{b}, *}$ \\ ${ }^{\text {a }}$ CEB - Centre of Biological Engineering, LIBRO - Laboratório de Investigação em Biofilmes Rosário Oliveira, University of Minho, Campus de Gualtar, 4710-057 Braga, \\ Portugal \\ ${ }^{\mathrm{b}}$ INL - International Iberian Nanotechnology Laboratory, Av. Mestre José Veiga, 4715-330 Braga, Portugal
}

\section{A R T I C L E I N F O}

\section{Keywords:}

Active packaging

Edible films

Phages cocktail

Cinnamaldehyde

Foodborne illness

Synergism

\begin{abstract}
A B S T R A C T
Notwithstanding the implementation of good processing practices in food companies and appropriate washing of food products by the consumer, Salmonella and Escherichia coli outbreaks continue to occur. In this study, different combinations of bacteriophages (phages) and cinnamaldehyde (CNMA) were incorporated on sodium alginate emulsion-based films to impart them with antimicrobial activity towards $S$. Enteritidis and E. coli. Films were prepared by casting and they were characterized in terms of CNMA and/or phages loading, thickness, moisture content, water vapor permeability (WVP), swelling index (SW), chemical interactions by FTIR, surface morphology by SEM and antimicrobial performance. Results showed that phages incorporation was not compromised by CNMA as evidenced by their viability inside the films. Increasing CNMA concentration yielded formulations less heterogeneous and a higher amount of CNMA loaded. Films characterization revealed that, in general, phages incorporation did not introduce significant changes on films parameters while the presence of CNMA increased the roughness, thickness and swelling ability of films. Sodium alginate films incorporated with EC4 and $\varphi 135$ phages displayed antimicrobial activity against $E$. coli and $S$. Enteritidis, respectively, while CNMA empowered the films with activity against both species. Combination of both phages with the higher concentration of CNMA resulted in a synergic antimicrobial effect against $E$. coli and a facilitative effect against Salmonella. Overall, incorporation of EC4 and $\varphi 135$ phages together with CNMA on alginate emulsion-based films holds great potential to be further applied in food packaging to prevent food contamination.
\end{abstract}

\section{Introduction}

Foodborne illness acquired from the consumption of contaminated food remains a serious threat, with a great impact on human health and economics. According to the World Health Organization (WHO, 2015), every year, about 600 million cases of foodborne illnesses and 420000 associated deaths occur worldwide (Hoelzer, Switt, Wiedmann, \& Boor, 2018). Among the microorganisms most frequently associated with foodborne outbreaks, Salmonella enterica and Escherichia coli play an important role (de Oliveira Elias, Noronha, \& Tondo, 2019). Salmonellosis, the illness caused by Salmonella, include symptoms such as diarrhea, fever and abdominal pain (CDC, 2018). Contamination of food products by $E$. coli may take place at different stages along the food chain, from production, processing, distribution until their final preparation by consumers (Sillankorva, Oliveira, \& Azeredo, 2012). The ability of these pathogens to grow on food matrices often leads to the establishment of microbial communities embedded on a self-produced extracellular matrix, known as biofilms, which confers them protection to antimicrobial agents (Galié, García-Gutiérrez, Miguélez, Villar, \& Lombó, 2018). Furthermore, the inappropriate use of antibiotics in both humans and animals (livestock industry) has led to an acceleration of microbial resistance (Jorge et al., 2019).

The best approach to deal with these challenges is to reduce the initial microbiological load and/or to prevent the growth of the remaining microorganisms on food products, by the use of an active packaging (Yildirim et al., 2018). Antimicrobial active packaging has been the focus of great interest due to the recent developments in materials science and engineering, the diversity in the methods of application and the variety of food products that can be protected (Khaneghah, Hashemi, \& Limbo, 2018).

Phages and essential oils have been charting their path to food safety in the last years, comprising, therefore, two promising agents to

\footnotetext{
* Corresponding author at: INL - International Iberian Nanotechnology Laboratory, Av. Mestre José Veiga, 4715-330 Braga, Portugal.

E-mail address: sanna.sillankorva@inl.int (S. Sillankorva).
} 
be incorporated into active packaging materials (Bhavaniramya, Vishnupriya, Al-Aboody, Vijayakumar, \& Baskaran, 2019; Sillankorva et al., 2012). Phages, the natural predators of bacteria, are, like all other viruses, obligate intracellular parasites, which means their replication requires the host's machinery. Lytic phages, the most suitable for food applications, interact with the host's cell surface molecular receptor, causing the cell wall to be penetrable for the incorporation of the nucleic acid, whereas the capsid remains outside the cell. Inside the host, phages are reproduced very quickly, forming new virus particles, and eventually cause lysis of the bacteria (Lin, Koskella, \& Lin, 2017). The increasing interest in phages for food application has resulted in the commercialization of phage-based products that have received regulatory approval from the Food and Drug Administration (FDA), such as EcoShield $^{\mathrm{TM}}$ and SalmoFresh ${ }^{\mathrm{TM}}$ (Moye, Woolston, \& Sulakvelidze, 2018). Most of encapsulation strategies reported for phages were driven by the need to protect them from the adverse conditions found in the digestive tract, such as the low $\mathrm{pH}$ and the activity of enzymes. In this context, phages have been encapsulated mostly in alginate-based microspheres (Abdelsattar, Abdelrahman, Dawoud, Connerton, \& ElShibiny, 2019; Colom et al., 2017; Moghtader, Eğri, \& Piskin, 2017) and liposomes (Otero et al., 2019). More recently, studies have reported phages encapsulation to be further applied in food products. For instance, the incorporation of phages targeting $E$. coli strains into matrices such as whey protein isolate (WPI) coatings/films (Huang \& Nitin, 2019; Tomat et al., 2019; Vonasek, Choi, Sanchez, \& Nitin, 2018) or chitosan (Amarillas et al., 2018) has proved to reduce the loss of phage activity during storage and to be a highly effective to prevent bacterial contamination of vegetable surfaces, meat, fish feed and tomatoes. A cocktail of phages targeting Salmonella has also been microencapsulated in WPI coatings and exhibited a high efficiency against Salmonella serovars, but it was less efficient when applied on fresh foods (Petsong, Benjakul, \& Vongkamjan, 2019). Phages incorporation on alginate films has also proved to prevent meat spoilage caused by Pseudomonas fluorescens (Alves et al., 2018).

Essential oils are volatile compounds naturally produced as secondary metabolites by plants with several biological properties such as antimicrobial activity. These compounds are considered Generally Recognized as Safe (GRAS) by the FDA to be added as food additives and they have been registered by the European Commission for use as flavouring in food context (Bhavaniramya et al., 2019). There are, however, some limitations associated to their use such as their volatility, low solubility in water and susceptibility for oxidation (RibeiroSantos, Andrade, \& Sanches-Silva, 2017). Furthermore, although the efficacy of essential oils has been demonstrated in vitro, higher concentrations are needed to achieve the same antimicrobial activity in food systems. Finally, the strong aroma of these compounds, may present a disadvantage for their use due to the negative organoleptic effects, overcoming the threshold acceptable to consumers (Hyldgaard, Mygind, \& Meyer, 2012). The best approach to circumvent these challenges also relies on their encapsulation, with the additional advantages of improving their biological activity and protecting them from interacting with food matrices (Bakry et al., 2016). Examples of essential oils and plant extracts added to different packaging materials include cinnamon oil (Simionato, Domingues, Nerín, \& Silva, 2019), oregano essential oil (Hashemi \& Mousavi Khaneghah, 2017), Rosmarinus officinalis essential oils (Hadian, Rajaei, Mohsenifar, \& Tabatabaei, 2017) and Rosemary and Aloe Vera oil (El Fawal, Omer, \& Tamer, 2019). Another option to decrease the concentration of essential oils, without jeopardizing their antimicrobial activity, can be achieved by their combination with other antimicrobial compounds to provide a synergistic effect. For instance, essential oils have been combined with silver nanoparticles (Cinteza et al., 2018; Scandorieiro et al., 2016) and the bacteriocin Nisin A and lactic acid, (Akhter, Masoodi, Wani, \& Rather, 2019). Only a few studies have reported the interactions between essential oils and phages when directly applied without previous encapsulation. For instance, the effect of a phage cocktail, alone and in combination with the essential oil trans-cinnamaldehyde on the viability of entero-hemorrhagic E. coli strains was investigated in a food model of baby romaine lettuce and baby spinach leaves. Results provided evidence that combination of these agents caused a faster antimicrobial effect than when each one was applied independently (Viazis, Akhtar, Feirtag, \& Diez-Gonzalez, 2011). In another study, the application of the essential oil alpha-pinene and phage $\mathrm{K}$ caused a higher reduction of $S$. aureus as compared to single applications (Ghosh, Ricke, Almeida, \& Gibson, 2016). To the best of our knowledge, the encapsulation of phages and essential oils for the development of an edible film/coating has not been reported so far.

The main goal of this work was to incorporate a cocktail of phages and CNMA, the major component of cinnamon leaf oil, on sodium-alginate emulsion-based films to fight food contamination by $E$. coli and $S$. Enteritidis.

\section{Materials and methods}

\subsection{Materials}

Alginate CR8223 (FMC BioPolymer) with M/G ratio of 65/35 and a molecular weight (MW) of $300 \mathrm{kDa}$ was kindly provided by FMC Health and Nutrition (USA). Glycerol $99.5 \%(\mathrm{v} / \mathrm{v}$ ) was purchased from Alfa Aesar (USA), Tris base and PEG 8000 were purchased from Fisher BioReagents $^{\mathrm{TM}}$ (USA), calcium chloride and $\mathrm{MgSO}_{4}$ from Panreac Applichem (Spain), cinnamaldehyde (CNMA, purity $\geq 95 \%$ ), Tween 80 and sodium chloride from Sigma-Aldrich (Portugal).

\subsection{Bacteria and phages}

Escherichia coli CECT 434 from the Spanish Type Culture Collection and Salmonella enterica serovar Enteritidis EX2 (Sillankorva et al., 2010) were used throughout this study. Bacteria were grown at $37^{\circ} \mathrm{C}$ in liquid LB broth (Liofilchem ${ }^{\circledast}$, Italy) or solid LB medium containing $1.2 \%(\mathrm{w} / \mathrm{v})$ of agar (Prolabo ${ }^{\circledast}$, Italy) (LBA) supplemented with kanamycin $(50 \mu \mathrm{g}$ / $\mathrm{mL}$, Nzytech, Portugal) or ampicillin (100 $\mu \mathrm{g} / \mathrm{mL}$, Nzytech, Portugal). The phages used were Salmonella phage $\varphi 135$ already partially characterized (Sillankorva et al., 2010), and the E. coli phage vB_EcoS-EC4 (EC4) that was isolated from raw sewage as previously described (Sillankorva, Neubauer, \& Azeredo, 2008a).

\subsection{Determination of minimal inhibitory and bactericidal concentrations of CNMA}

The minimal inhibitory (MIC) and bactericidal (MBC) concentrations of CNMA against Salmonella and E. coli were determined by the microdilution method according to Clinical and Laboratory Standards Institute (CLSI, 2003). Briefly, the wells of a sterile 96-well roundbottom microtiter plates (polystyrene, Orange, USA) were filled with $100 \mu \mathrm{L}$ of Mueller-Hinton broth (MHB, Liofilchem ${ }^{\circledR}$, Italy) with increasing concentrations of CNMA to which were added $100 \mu \mathrm{L}$ of each bacterium inoculums (adjusted to a final concentration of $5.0 \times 10^{5} \mathrm{CFU} / \mathrm{mL}$ ). The plates were afterwards incubated at $37{ }^{\circ} \mathrm{C}$ for $24 \mathrm{~h}$ in an orbital shaker at $120 \mathrm{rpm}$. In this assay, two controls were used, one without bacteria as a negative control and one without CNMA as a positive control. Moreover, culture media with increasing concentrations of antimicrobials without bacteria were also performed in order to avoid misleading results. The MIC was obtained by measuring the absorbance at $620 \mathrm{~nm}\left(\mathrm{~A}_{620 \mathrm{~nm}}\right)$ on a microtiter plate reader (TECAN Sunrise), where clear wells $\left(\mathrm{A}_{620 \mathrm{~nm}}=\right.$ negative control) were evidence of bacterial growth inhibition. MBC determination was performed by adding a droplet of $10 \mu \mathrm{L}$ from each well with no visible growth on a LBA plate. The lowest concentration that yielded no colony growth after $24 \mathrm{~h}$ at $37^{\circ} \mathrm{C}$ was identified as the MBC. Two independent assays with four replicates for each condition were performed. 


\subsection{Phages production and titration}

Phages were produced using the plate lysis and elution method previously described by Sambrook and Russel, with some modifications (Sambrook \& Russel, 2001). Briefly, $10 \mu \mathrm{L}$ of phage suspension was spread on Salmonella or E. coli lawns using a paper strip and incubated overnight at $37^{\circ} \mathrm{C}$. Afterwards, $3 \mathrm{~mL}$ of SM buffer [100 mM NaCl, $8 \mathrm{mM}$ $\mathrm{MgSO}_{4}, 50 \mathrm{mM}$ Tris/ $\mathrm{HCl}$ ( $\mathrm{pH}$ 7.5)] were added to each plate and incubated for $6 \mathrm{~h}$, at $4{ }^{\circ} \mathrm{C}$ and $90 \mathrm{rpm}$ (Orbital Shaker ES-20/60, BIOSAN, Latvia). The liquid and top-agar were collected, centrifuged (10 $\mathrm{min}, 10$ $000 \mathrm{~g}, 4^{\circ} \mathrm{C}$ ), further concentrated with $0.1 \mathrm{M} \mathrm{NaCl}$ and incubated for $1 \mathrm{~h}$ at $4{ }^{\circ} \mathrm{C}$. The lysate was centrifuged $\left(10 \mathrm{~min}, 10000 \mathrm{~g}, 4{ }^{\circ} \mathrm{C}\right)$ and the supernatant further concentrated with $10 \%(\mathrm{w} / \mathrm{v})$ PEG 8000 and finally purified with chloroform 1:4 (v/v). Samples in SM buffer were stored at $4{ }^{\circ} \mathrm{C}$ until further use. Phage titration was performed according to Adams (Adams, 1959). Briefly, $100 \mu \mathrm{L}$ of diluted phage solution, $100 \mu \mathrm{L}$ of overnight culture of Salmonella or E. coli, and $3 \mathrm{~mL}$ of molten agar were poured into a petri dish containing a thin layer of LBA. Plates were incubated at $37{ }^{\circ} \mathrm{C}$ overnight and plaque forming units (PFU) were enumerated.

\subsection{Phage EC4 characterization}

Phage EC4 was characterized according to its plaque morphology by imaging using a Nikon stereoscopic microscope. For this, ten different phage plaques were measured in terms of the plaque and halo diameter. Virion particle morphology was analysed by transmission electron microscopy. Briefly, phage particles were sedimented by centrifugation $\left(17,000 \mathrm{~g}, 90 \mathrm{~min}, 4^{\circ} \mathrm{C}\right)$, washed twice in tap water, and centrifuged again. The suspension ( $5 \mu \mathrm{L}$ ) was deposited on copper grids ( 400 mesh, Pelco $^{\circledast}$, Ted Pella, Inc., USA), stained with $2 \%(\mathrm{w} / \mathrm{v})$ uranyl acetate (pH 4.0) (Electron Microscopy Sciences, Pennsylvania, USA) and imaged using a Jeol JEM-2100-HT transmission electron microscope (Tokio, Japan). Images were digitally recorded using a UltraScan ${ }^{\circledast} 4000$ CCD camera (Oneview, Gatan, California, USA). Growth parameters of EC4 were determined through one-step growth characterization as previously described (Sillankorva et al., 2008a). Briefly, $10 \mathrm{~mL}$ of a midexponential-phase culture was harvested by centrifugation $(7000 \mathrm{~g}$, $5 \mathrm{~min}, 4^{\circ} \mathrm{C}$ ) and the supernatant discarded. The pellet was suspended in $5 \mathrm{~mL}$ fresh LB medium and the optical density adjusted to 1.0. To this suspension, $5 \mathrm{~mL}$ of phage solution were added in order to have a MOI of 0.001 . Adsorption was allowed to occur for $5 \mathrm{~min}$ at room temperature. The mixture was then centrifuged as described above and the pellet was suspended in $10 \mathrm{~mL}$ of fresh LB medium. Samples were taken every 5 min over a period of $1 \mathrm{~h}$ and immediately plated.

\subsection{Preparation of sodium alginate films and incorporation of phages and cinnamaldehyde}

Sodium alginate-based films were prepared as previously described (Costa et al., 2018) and phages incorporation was performed as described before (Alves et al., 2018). Briefly, sodium alginate $[1 \%(\mathrm{w} / \mathrm{v})]$ was completely dissolved in distilled water, at room temperature, glycerol was added at a final concentration of $0.5 \%(\mathrm{v} / \mathrm{v})$, and the solution was stirred overnight at room temperature. Phages were added to alginate $1: 13(\mathrm{v} / \mathrm{v})$ in order to have a final concentration of approximately $10^{9} \mathrm{PFU} / \mathrm{mL}$, and the solution further stirred for $30 \mathrm{~min}$ at room temperature. Cinnamaldehyde was added to film-forming solutions with and without phages, at different concentrations $[0.3 \%$ and $0.4 \%$ $(\mathrm{v} / \mathrm{v})]$ together with Tween $80[0.1 \%(\mathrm{w} / \mathrm{v})]$ as an emulsifier. The solution was homogenized by constant stirring at $350 \mathrm{rpm}$ for $40 \mathrm{~min}$. To produce the films, $28 \mathrm{~mL}$ of film-forming solution was cast onto a Petri dish $\left(9.2 \mathrm{~cm}\right.$ of diameter) and dried for two days at $30{ }^{\circ} \mathrm{C}$. The dried films were crosslinked with calcium chloride as previously described (Alves et al., 2018), and left to dry at room temperature for $24 \mathrm{~h}$ and finally the films were put in desiccators containing a saturated solution of $\mathrm{Mg}\left(\mathrm{NO}_{3}\right)_{2} \cdot 6 \mathrm{H}_{2} \mathrm{O}$ (Alfa Aesar, Germany) at $53 \%$ of relative humidity (RH) and $20{ }^{\circ} \mathrm{C}$ before subjected to characterization experiments or at $4{ }^{\circ} \mathrm{C}$ until the antimicrobial experiments.

\subsection{CNMA emulsions characterization}

The size distribution of CNMA emulsions, prepared at $0.3 \%$ and $0.4 \%(\mathrm{v} / \mathrm{v})$, was determined by dynamic light scattering (DLS) using a Malvern Zetasizer, Model NANO ZS (Malvern Instruments Limited, UK). Analysis were performed at $25{ }^{\circ} \mathrm{C}$ in a polystyrene cell, using a He-Ne laser-wavelength of $633 \mathrm{~nm}$ and a detector angle of $173^{\circ}$.

\subsection{Phage titre and cinnamaldehyde quantification after incorporation in sodium alginate-based films}

The dried films were peeled from the Petri dishes and cut into $2 \times 2 \mathrm{~cm}^{2}$ square pieces. The titre of incorporated phages and/or CNMA was determined by placing the films in $2 \mathrm{~mL}$ of SM buffer, subjecting them to vigorous agitation (250 rpm, Orbital Shaker ES-20/ 60 , BIOSAN, Latvia) for $45 \mathrm{~min}$, at room temperature, to promote their release. The number of active phage particles was determined by PFU enumeration. The concentration of CNMA was assessed as described previously (Cerqueira et al., 2016) by measuring the absorbance at $330 \mathrm{~nm}$ (Jasco V560 Spectrophotometer). For each experimental condition, at least three replicates were performed.

\subsection{Fourier transform infrared spectroscopy}

Fourier transform infrared (FTIR) spectra of the films were recorded with a Bruker FT-IR VERTEX 80/80v (Boston, USA) in Attenuated Total Reflectance mode (ATR) with a platinum crystal accessory in the wavenumber range: $4000-400 \mathrm{~cm}^{-1}$, using 16 scans at a resolution of $4 \mathrm{~cm}^{-1}$. Prior analysis, an open bean background spectrum was recorded as a blank.

\subsection{Films morphology}

The morphology of films surface was observed using scanning electron microscopy (SEM) (Quanta FEG 650, FEI, USA) with an accelerating voltage of $5 \mathrm{kV}$. Prior analysis, samples were mounted on aluminium stubs using carbon adhesive tape and sputter-coated with gold.

\subsection{Films thickness}

Films thickness was measured with a hand-held electronic digital micrometre with a sensitivity of $0.001 \mathrm{~mm}$. Ten measurements were taken in different points of each film and the mean values were used in permeability calculations.

\subsection{Water vapour permeability (WVP)}

Water vapour permeability of the films was determined using a modified ASTM (1983) procedure (Casariego et al., 2009; Guillard, Broyart, Bonazzi, Guilbert, \& Gontard, 2003). Films were sealed on the top of permeation cells containing distilled water and placed inside a desiccator which was kept at $20{ }^{\circ} \mathrm{C}$ and $0 \% \mathrm{RH}$ with silica. The water transferred through the film and adsorbed by the desiccant was determined from weight loss of the permeation cell. For that, cups were weighed at intervals of approximately $2 \mathrm{~h}$, for a total of $10 \mathrm{~h}$. Water vapour transmission rate (WVTR) was then calculated by dividing the slope of a linear regression of weight loss versus time by film area, and WVP $\left[\mathrm{g} /\left(\mathrm{m}^{2} \mathrm{~s}^{1}\right)\right]$ as follows:

$W V P=\frac{(W V T R \times L)}{\Delta P}$ 

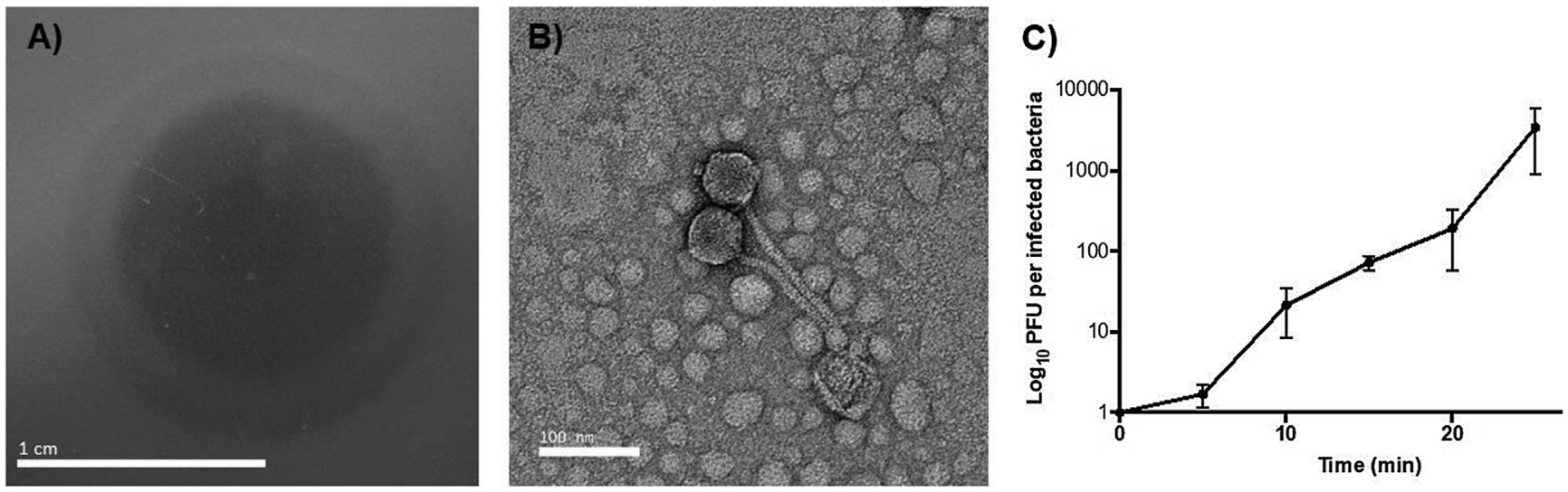

Fig. 1. Characteristics of phage EC4. (A) Plaque morphology, (B) TEM micrograph, (C), phage growth characteristics.

where $L$ is the film thickness $(\mathrm{m})$ and $\Delta P$ is the water vapor partial pressure difference $(\mathrm{Pa})$ across the two sides of the film. Three replicates were made for each film sample.

\subsection{Swelling index and moisture content}

The swelling index of films was determined as previously described (Cao, Fu, \& He, 2007), with some modifications. Films were cut into $2 \times 2 \mathrm{~cm}^{2}$ square pieces and their weight was measured. Samples were, afterwards, immersed in distilled water for $24 \mathrm{~h}$ at room temperature. Paper filter was used to remove liquid excess and the final weigh was measured. The amount of absorbed water, in percentage, was calculated using Eq. (2) in which $S_{1}$ is the weight of the film after immersion and $S_{O}$ is the initial weight of the film. All measurements were performed in triplicate for each experimental condition.

$S W=\frac{\left(S_{1}-S_{0}\right)}{S_{0}} \times 100$

The moisture content (MC) was determined by drying $2 \times 2 \mathrm{~cm}^{2}$ square pieces of films at $105{ }^{\circ} \mathrm{C}$ for $24 \mathrm{~h}$ (until reaching the equilibrium weight). The weight loss of the sample was determined and used to calculate the moister content according to Eq. (3), where $M_{i}$ and $M_{f}$ are the masses of initial and dried samples, respectively.

$M C=\left(\frac{M i-M f}{M i}\right) \times 100$

\subsection{Antimicrobial activity}

The antimicrobial activity of films was performed according to the Standard 206 JIS 2801 (Association, 2000), with some modifications. Briefly, a bacterial suspension of Salmonella or E. coli adjusted to a final concentration of $10^{6} \mathrm{CFU} / \mathrm{mL}$ was prepared in $\mathrm{LB}$, of which $50 \mu \mathrm{L}$ were added on top of each film $\left(2 \times 2 \mathrm{~cm}^{2}\right)$. Sodium alginate films without phages or CNMA were used as controls. Samples, in triplicate, were placed in Petri dishes, sealed with parafilm and were incubated for $24 \mathrm{~h}$ at $20{ }^{\circ} \mathrm{C}$. Films were placed in saline solution $[\mathrm{NaCl} 0.9 \%(\mathrm{w} / \mathrm{v})]$, subjected to vigorous agitation (250 rpm, Orbital Shaker ES-20/60, BIOSAN) for $15 \mathrm{~min}$ at room temperature, in order to promote bacterial detachment. The number of colony forming units (CFU) was determined by plating serial dilutions. Plates were incubated overnight at $37{ }^{\circ} \mathrm{C}$ under aerobic conditions. Three independent assays with three replicates for each condition tested were performed.

To better understand the antimicrobial effect obtained from the combination of CNMA and phages, a previously reported methodology was applied (Chaudhry et al., 2017) to classify the effects obtained as synergism or facilitation. The term "synergism" was used to classify an outcome in which combined treatment kills greater fraction of bacteria than expected if the compounds were acting independently. "Facilitation" also comprises an interest outcome and it was used to classify an outcome in which combined treatment is better than the best of the single treatments, but it is not better than if the antimicrobials were acting independently. For their calculation, an outcome was classified as facilitation when both the equations $\log \left(S_{A B}\right)-\log \left(S_{A}\right)<0$ and $\log \left(S_{A B}\right)-\log \left(S_{B}\right)<0$ were valid. Synergism was obtained when the equation $\log \left(S_{C}\right)-\log \left(S_{A}\right)-\log \left(S_{B}\right)+\log \left(S_{A B}\right)<0$ was valid. In these equations, $C$ refers to the cell density obtained in the control (sodium alginate films) and $S_{A}, S_{B}$ and $S_{A B}$ refers to the surviving cell density after being in contact with films entrapped with agent $A$, agent $B$ and the combination of $\mathrm{A}$ and $\mathrm{B}$.

\subsection{Statistical analysis}

Results are presented as a mean \pm standard deviation (SD). Statistical analysis was performed using Graph Pad Prism 7.0. To compare films thickness, moister content, swelling index and WVP, oneway ANOVA followed by Dunnet's test was implemented. Antimicrobial activity of films with and without phages and/or CNMA as well as the titre of phages inside the films was determined using a Two-way ANOVA, followed by a Tukey's test. Emulsions z-average and PDI were tested by an unpaired $t$ test with Welch's correction. In all the analysis, the used confidence interval was $95 \%$.

\section{Results and discussion}

\subsection{Characterization of phages}

The phages used in this work were the Salmonella phage $\varphi 135$ and $E$. coli phage EC4. Phage $\varphi 135$ has been previously characterized and belongs to the Siphoviridae family with a long non-contractile tail (Milho, 2019; Sillankorva et al., 2010). This phage forms clear plaques on its host bacterium, has a latent period of approximately $30 \mathrm{~min}$ and a burst size of 162.9 particles per infected cell (Milho et al., 2018). Phage EC4 forms clear plaques on its host (Fig. 1a) averaging a diameter of $9.98 \pm 0.92 \mathrm{~cm}$, that is surrounded by a halo that results in a total plaque diameter of $14.12 \pm 1.43$. This phage also belongs to the Siphoviridae family (Fig. $1 \mathrm{~b}$ ), and it has a very short latent period ( $5 \mathrm{~min}$ ) and a burst of approximately $132 \mathrm{PFU}$ per infected bacteria (Fig. 1c).

\subsection{Antimicrobial activity of CNMA towards planktonic cultures of $S$. Enteritidis EX2 and E. Coli 434}

The concentrations of CNMA able to inhibit planktonic bacterial growth and those required to kill them are summarised in Table 1. CNMA was effective at low concentrations and similar susceptibility 
Table 1

Minimal inhibitory (MIC) and bactericidal (MBC) concentrations of CNMA against planktonic cultures of $S$. Enteritidis EX2 and E. coli 434.

\begin{tabular}{llc}
\hline Strain & MIC $(\mathrm{mg} / \mathrm{L})$ & MBC $(\mathrm{mg} / \mathrm{L})$ \\
\hline E. coli 434 & 160 & $310-620$ \\
S. Enteritidis EX2 & 160 & $310-620$ \\
\hline
\end{tabular}

patterns were found for both species investigated in this study. The concentrations found are in accordance to previous studies (Burt et al., 2016; Pei, Zhou, Ji, \& Xu, 2009) and were lower than the ones found for others essential oils (oregano, thyme and clove) tested against the same species (Lara et al., 2016; Solarte et al., 2018). Furthermore, MIC and MBC values almost coincided (two-fold difference), which indicates that CNMA killing is generally bactericidal, a highly desirable mode of action to control microbial contamination (Ocampo et al., 2014).

\subsection{Incorporation of phages and/or CNMA on sodium-alginate films}

Sodium alginate-based matrices have been found suitable to incorporate different phages (Colom et al., 2017; Moghtader et al., 2017). In this work, similar titres of entrapped phages (Table 2) were obtained as compared to a previous work, which attests the efficiency of the entrapment strategy (Alves et al., 2018). Comparing the titer of phages initially entrapped and the titers retrieved inside the films, a loss on phages viability was observed ( $3 \mathrm{Log}$ ). It may be attributed to the entrapment process, during which phages are inevitably exposed to shear stress trough mixing and agitation and further desiccation stress during the drying step (Malik et al., 2017). The combination of CNMA with both phages used herein did not interfere with their viability inside the alginate films, as similar titres were obtained when phages were entrapped together with CNMA.

For CNMA incorporation, two emulsion formulations were evaluated, differing on the amount of essential oil added. A slight increase on CNMA amount yielded a significant (more than double) increase on CNMA concentration incorporated on alginate films (Table 3).

Both formulations were then characterized in terms of particle size (Fig. 2). Size distributions of CNMA formulations with $0.3 \%$ showed two peaks, corresponding to CNMA droplets with sizes of $625.58 \pm 181.19 \mathrm{~nm}$ and $18.59 \pm 4.41 \mathrm{~nm}$. The minor peaks found at the nano-range could be associated with emulsifier micelles that were not adsorbed at the oil-water interface of the emulsions, as previously described (Rao \& McClements, 2012). Increasing CNMA concentration to $0.4 \%$ yielded a formulation less heterogeneous as evidenced by the lower PDI found and droplets with bigger size $(1613.2 \pm 377.5 \mathrm{~nm})$ as previously reported (Frank, Garcia, Shin, \& Kim, 2018).

\subsection{Morphology and FTIR characterization of films}

The surface morphology of different film samples was imaged using SEM (Fig. 2). The control sodium alginate films devoid of phages and CNMA, exhibit an homogenous and smooth surface with small aggregate structures which have been previously attributed to the calcium

Table 2

Titre of phages $\varphi 135$ and EC4 inside sodium alginate-based films in the presence $(+)$ and absence $(-)$ of CNMA.

\begin{tabular}{lll}
\hline \multirow{2}{*}{ Phage } & Titre $\left(\mathrm{PFU} / \mathrm{cm}^{2}\right)$ \\
\cline { 2 - 3 } & CNMA $(-)$ & CNMA $(+)$ \\
\hline$\varphi 135$ & $(3.91 \pm 3.93) \times 10^{6 \mathrm{a}}$ & $(2.4 \pm 2.69) \times 10^{7 \mathrm{a}}$ \\
EC4 & $(3.28 \pm 2.19) \times 10^{6 \mathrm{a}}$ & $(6.58 \pm 2.00) \times 10^{6 \mathrm{a}}$ \\
\hline
\end{tabular}

\footnotetext{
a Means that values in the same column or line do not differ statistically $(p>0.05)$.
}

Table 3

Quantification of CNMA inside the sodium alginate-based films for different concentrations of CNMA.

\begin{tabular}{ll}
\hline Film samples & Mass per Area $\left(\mu \mathrm{g} / \mathrm{cm}^{2}\right)$ \\
\hline CNMA $0.3 \%$ & $8.72 \pm 0.49$ \\
CNMA $0.4 \%$ & $20.37 \pm 2.95$ \\
\hline
\end{tabular}

chloride crosslinking and the "egg-box" structure formed by the interactions between alginate and the calcium ions (Costa et al., 2018). Phages incorporation did not introduce significant changes on films morphology (Fig. 2B, 2C and 2J). CNMA incorporation (Fig. 2D and $2 \mathrm{E}$ ), on the other hand, resulted in increased roughness as compared to control surfaces, being this observation also evident when CNMA was combined with phages (Fig. 2F, 2G, 2H, 2I, 2K and 2L). Increase in roughness can be attributed to the agglomeration associated to an uneven dispersion of hydrophobic molecules during the film's formation process (Wu, Sun, Guo, Ge, \& Zhang, 2017). The morphological characterization of films is corroborated by the thickness values obtained (Table 4). Sodium alginate films exhibited a thickness of $31.3 \pm 7.3 \mu \mathrm{m}$. Each phage alone or both together in the absence of CNMA, had no significant effect on this parameter. Films thickness, however, was increased by CNMA incorporation and further increased when CNMA was combined with each phage alone or both phages together that can be explained by the increase of the solids amount in the film with the addition of the emulsion.

FTIR analysis were performed to identify the presence of new chemical bonds or the modification of existing ones, which can be attributed to possible interactions between sodium alginate and CNMA and/ or phages. Spectra of films before and after incorporation of CNMA and/or phages (Fig. 3) showed major peaks in the wavenumber ranged between $600 \mathrm{~cm}^{-1}$ and $1800 \mathrm{~cm}^{-1}$ in addition to the peaks found between 3700 and $3000 \mathrm{~cm}^{-1}$ which correspond to stretching vibration of the $\mathrm{O}-\mathrm{H}$ bonds (Voo et al., 2015), and between 3000 and $2850 \mathrm{~cm}^{-1}$ related to $\mathrm{C}-\mathrm{H}$ stretching (Lawrie et al., 2007). The characteristic absorption bands of alginate (Fig. 3A) were found at $1595 \mathrm{~cm}^{-1}$ (asymmetric stretching vibration of $\mathrm{C}-\mathrm{O}$ bond of $\mathrm{COO}^{-}$group) (Costa et al., 2018), at $1408 \mathrm{~cm}^{-1}$ (symmetric stretching vibration of $\mathrm{C}-\mathrm{O}$ in the $\mathrm{COO}^{-}$group) (Pereira, Tojeira, Vaz, Mendes, \& Bártolo, 2011), at $1028 \mathrm{~cm}^{-1}$ (antisymmetric stretch of C-O-C) (Lawrie et al., 2007), and at $818 \mathrm{~cm}^{-1}$ (characteristic peak of mannuronic acid residues) (Fertah, Belfkira, Dahmane, Taourirte, \& Brouillette, 2017). The spectra of the alginate films after phages (Fig. 3A) and/or CNMA incorporation (Fig. 3B and C), were similar to the alginate control in the range between $600 \mathrm{~cm}^{-1}$ and $1800 \mathrm{~cm}^{-1}$, but some changes were observed between 3000 and 3600 which suggests some interactions with CNMA and alginate chains. An additional peak was observed at approximately $1670 \mathrm{~cm}^{-1}$ which may be explained by the stretching of the aldehyde group.

\subsection{Moisture content, water vapour permeability and swelling index}

In order to investigate in what extent the incorporation of CNMA and/or phages in alginate films influences the water affinity to the alginate film matrix, moisture content (MC) of the films was determined (Table 4). Sodium alginate films exhibit low values of MC, that is reduced after incorporation of CNMA at $0.3 \%$; which is in accordance to a previously reported study using cinnamon oil $(0.25 \%)$ and it may be attributed to the small particles sized obtained (Perdones, Vargas, Atarés, \& Chiralt, 2014). These results suggest that CNMA molecules interacted with alginate chains blocking some active groups needed for water interaction (Fabra, Talens, \& Chiralt, 2010). Phages incorporation had no interference on alginate films affinity to water, as evidenced by the similar MC values found. When phages were added together with CNMA, the water affinity increased to similar values of alginate films. It 
A)

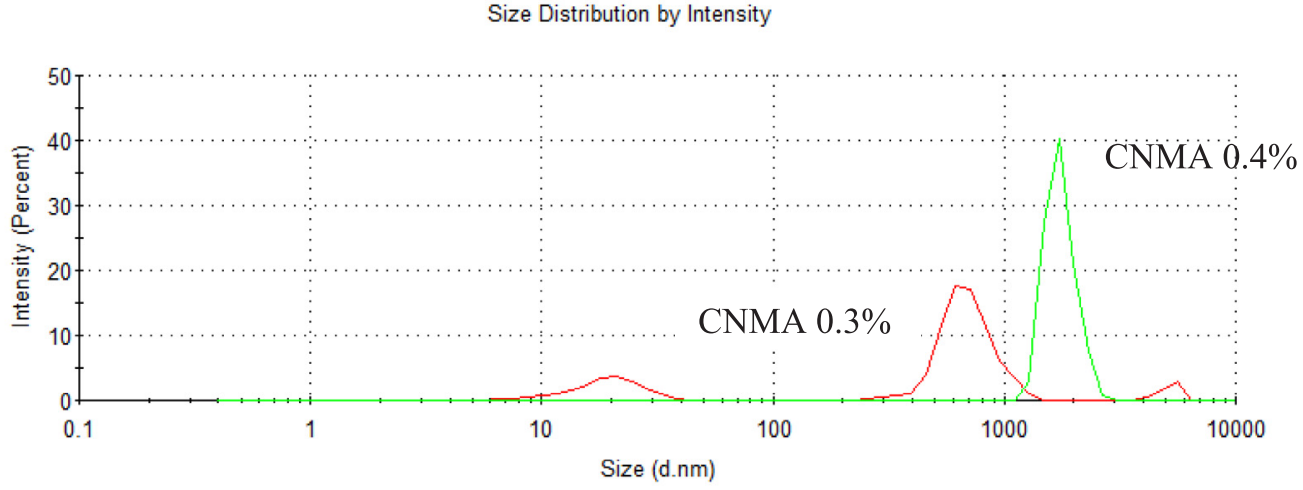

B)

\begin{tabular}{ccc}
\hline Formulation & z-Average $(\mathbf{n m})$ & PDI \\
\hline CNMA 0.3\% & $626 \pm 181.2^{\mathrm{a}}$ & $0.9 \pm 0.1^{\mathrm{a}}$ \\
CNMA 0.4\% & $1613 \pm 377.5^{\mathrm{b}}$ & $0.5 \pm 0.2^{\mathrm{b}}$
\end{tabular}

$\overline{\mathrm{a}, \mathrm{b}}$ Means in the same column with different superscripts are significantly different $(\mathrm{p}<0.05)$.

Fig. 2. Effect of CNMA concentration on the (A) size distribution and subsequent (B) mean droplet size and polydispersity index (PDI).

Table 4

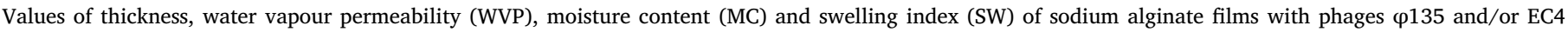
entrapped in the presence and absence of CNMA.

\begin{tabular}{|c|c|c|c|c|}
\hline Film samples & Thickness $(\mu \mathrm{m})$ & MC (\%) & $\mathrm{WVP} \times 10^{-11}\left[\mathrm{~g}\left(\mathrm{~m} \mathrm{~s} \mathrm{~Pa}^{-1}\right]\right.$ & SW (\%) \\
\hline Control & $31.3 \pm 7.3^{\mathrm{a}}$ & $20.34 \pm 1.13^{\mathrm{ac}}$ & $5.15 \pm 1.18^{\mathrm{a}}$ & $767 \pm 67^{\mathrm{ac}}$ \\
\hline$\varphi 135$ & $38.2 \pm 3.9^{\mathrm{a}}$ & $22.28 \pm 2.93^{\mathrm{ac}}$ & $3.15 \pm 0.17^{\mathrm{a}}$ & $939 \pm 257^{\mathrm{abc}}$ \\
\hline EC4 & $45.0 \pm 15.0^{\mathrm{a}}$ & $18.13 \pm 1.40^{\mathrm{abc}}$ & $3.70 \pm 0.97^{\mathrm{a}}$ & $764 \pm 131^{\mathrm{ac}}$ \\
\hline CNMA $0.3 \%$ & $42.3 \pm 6.3^{\mathrm{a}}$ & $12.64 \pm 0.24^{\mathrm{b}}$ & $5.62 \pm 1.4^{\mathrm{a}}$ & $1193 \pm 102^{\mathrm{bc}}$ \\
\hline CNMA $0.4 \%$ & $44.1 \pm 6.3^{\mathrm{a}}$ & $15.50 \pm 1.88^{\mathrm{ab}}$ & $4.88 \pm 2.37^{\mathrm{a}}$ & $1053 \pm 174^{\mathrm{abc}}$ \\
\hline$\varphi 135$ and CNMA $0.3 \%$ & $84.6 \pm 18.5^{\mathrm{ab}}$ & $18.61 \pm 0.93^{\mathrm{abc}}$ & $9.68 \pm 7.6^{\mathrm{a}}$ & $1005 \pm 75^{\text {abc }}$ \\
\hline$\varphi 135$ and CNMA $0.4 \%$ & $80.6 \pm 13.9^{\mathrm{ab}}$ & $19.64 \pm 1.90^{\mathrm{ac}}$ & $6.64 \pm 0.59^{\mathrm{a}}$ & $829 \pm 120^{\mathrm{ac}}$ \\
\hline EC4 and CNMA $0.3 \%$ & $65.8 \pm 17.0^{\mathrm{ab}}$ & $14.56 \pm 1.01^{\mathrm{ac}}$ & $8.69 \pm 2.88^{\mathrm{a}}$ & $660 \pm 76^{\mathrm{a}}$ \\
\hline EC4 and CNMA $0.4 \%$ & $57.5 \pm 7.1^{\mathrm{a}}$ & $22.46 \pm 1.43^{c}$ & $4.73 \pm 0.18^{\mathrm{a}}$ & $794 \pm 56^{\mathrm{ac}}$ \\
\hline$\varphi 135$ and EC4 & $39.5 \pm 4.7^{\mathrm{b}}$ & $17.92 \pm 0.78^{\mathrm{abc}}$ & $3.25 \pm 0.033^{\mathrm{a}}$ & $924 \pm 61^{\mathrm{abc}}$ \\
\hline$\varphi 135$ and EC4 and CNMA $0.3 \%$ & $92.4 \pm 21.3^{\mathrm{ab}}$ & $19.56 \pm 4.95^{\mathrm{ac}}$ & $10.1 \pm 4.59^{\mathrm{a}}$ & $852 \pm 13^{\mathrm{abc}}$ \\
\hline$\varphi 135$ and EC4 and CNMA $0.4 \%$ & $60.0 \pm 14.1^{\mathrm{a}}$ & $19.48 \pm 0.35^{\mathrm{ac}}$ & $4.94 \pm 0.89^{\mathrm{a}}$ & $671 \pm 65^{\mathrm{a}}$ \\
\hline
\end{tabular}

a,b,c Means in the same column with different superscripts are significantly different $(p<0.05)$.

has been described that some phages (e.g. P22) have a hydrophilic nature after PEG purification (Shi \& Tarabara, 2018) which could, in part, explain this observation, nevertheless, further studies should be performed to confirm this hypothesis.

The WVP values found for the films investigated show that alginate films exhibit a WVP value (Table 4) of $(5.15 \pm 1.18) \times 10^{-11} \mathrm{~g}$ $(\mathrm{msPa})^{-1}$, similar to the one previously obtained by (Costa et al., 2018). The permeability of the films was not significantly changed ( $p>0.05)$ after incorporation of compounds alone or combined. Since vapour migration occurs through the hydrophilic fraction of a film, it was expected that the addition of CNMA, a hydrophobic compound, would reduce WVP as observed in previous studies (Cerqueira et al., 2016; Du et al., 2009), however, this did not occur. It has been reported that essential oils have the ability to plasticize polymeric films, weakening hydrogen bonding and allowing greater WVP (Otoni, AvenaBustillos, Olsen, Bilbao-Sáinz, \& McHugh, 2016).

Rehydration of the films is another important property when films undergo a swelling process, and this was determined (Table 4). Alginate films show a high index of swelling corroborating a previous study (Costa et al., 2018), and phages incorporation did not interfere with the swelling properties, which is in accordance to a previous study using other phage (Alves et al., 2018). Contrarily to what was expected, due to the hydrophobic nature of CNMA, the incorporation of CNMA increased the swelling ability of the films when $0.3 \%(\mathrm{v} / \mathrm{v})$ was used. The aforementioned plasticizing effect may be the explanation for these results. When CNMA was incorporated with both phages, in general, similar swelling properties were found as compared to control alginate films.

\subsection{Antimicrobial study}

The antimicrobial activity of the different films against two pathogenic species commonly found associated to foodborne illness, $S$. Enteritidis and E. coli (McLinden, Sargeant, Thomas, Papadopoulos, \& Fazil, 2014) was studied (Fig. 4). Both species were able to grow on sodium alginate films reaching approximately 8 and 7 Log viable cells 

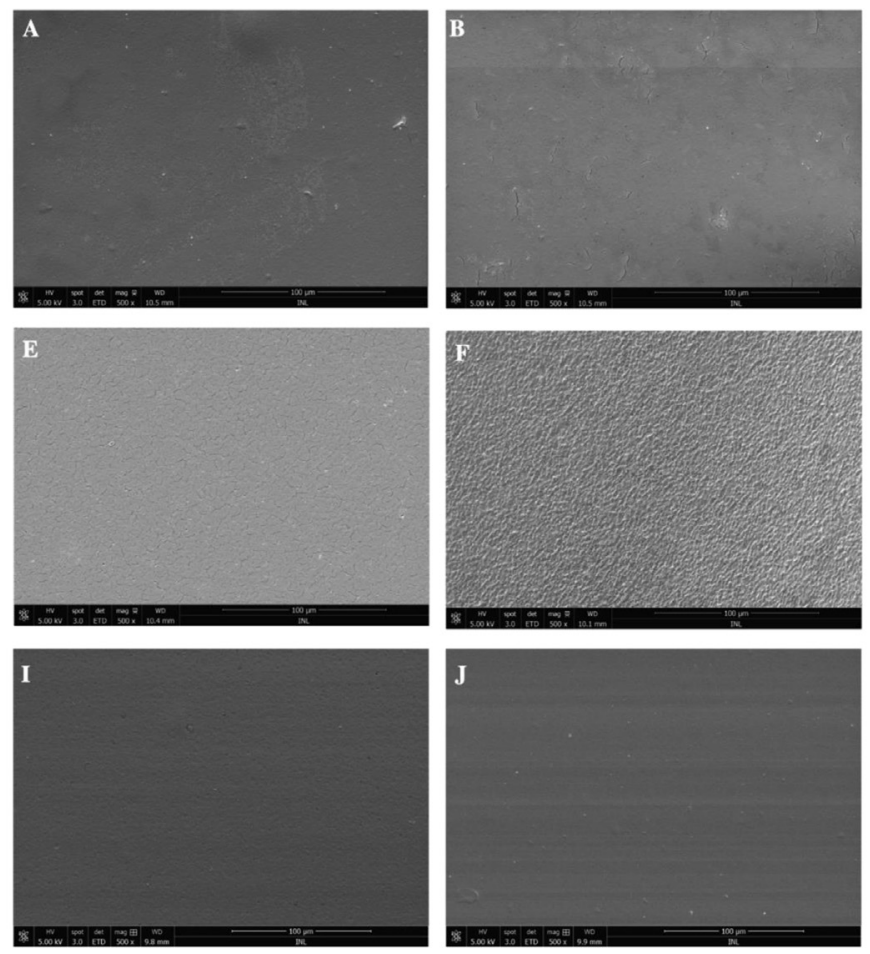
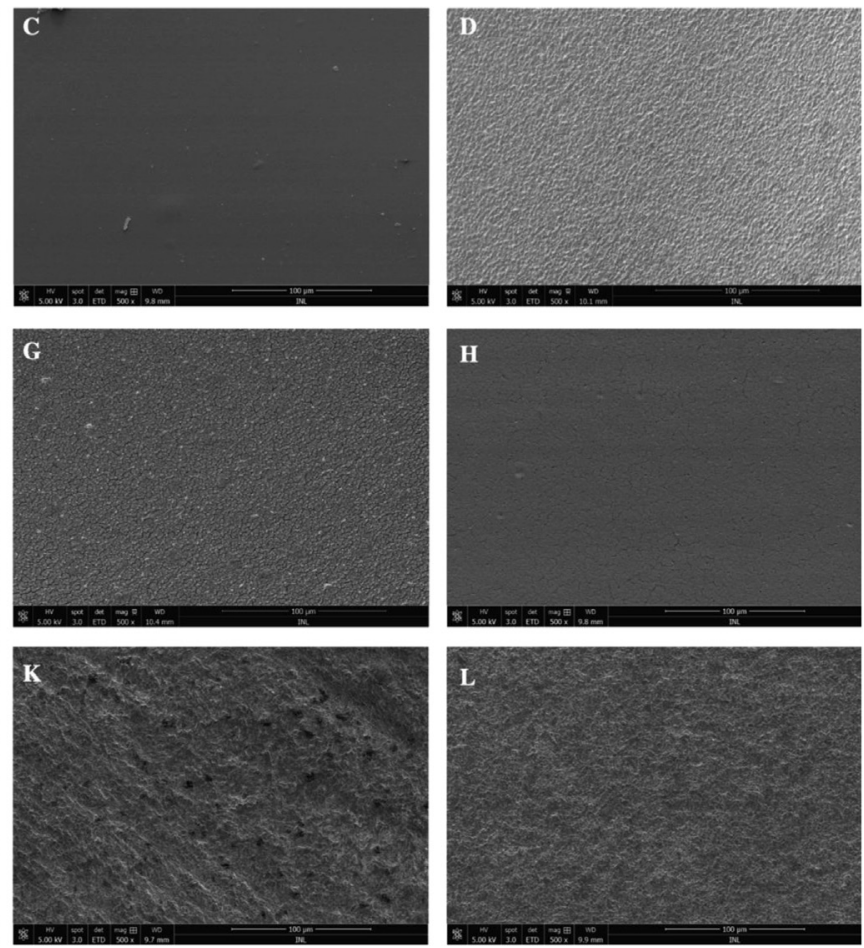

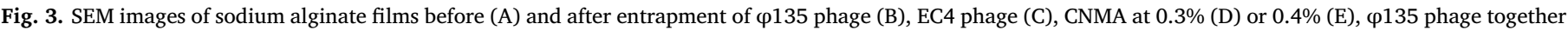

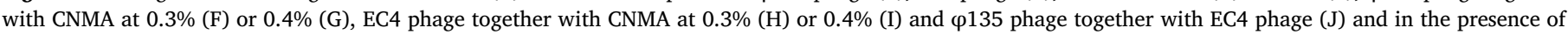
CNMA at $0.3 \%(\mathrm{~K})$ or $0.4 \%(\mathrm{~L})$.

of $S$. Enteritidis and E. coli, respectively. Films with EC4 or $\varphi 135$ phages incorporated (Fig. 4A and 4B), impaired the growth of E. coli and Salmonella, respectively, as evidenced by a $1.4 \mathrm{Log}$ of $E$. coli cells and a statistically significant $5.1 \mathrm{Log}$ reduction of Salmonella. This major difference in viable cell reductions was not expected, since both phages have fairly similar burst sizes with EC4 reaching approximately 132 PFU per infected bacteria (Fig. 1) and $\varphi 135$ resulting in about 163 PFU per infected cell (Milho, 2019). There are, however, differences in the length of the latent periods, with EC4 presenting a shorter period (5 min) than $\varphi 135$ (30 min) (Milho, 2019), respectively (Fig. 1c). Short latent periods are presumed to be beneficial while long periods may result in negative treatment outcomes (Bull \& Gill, 2014). Nevertheless, 5 and $30 \mathrm{~min}$ are still considered to be quite short latent periods and thus, this difference in periods does not suffice to respond to the different killing effect of these phages in these two bacterial species. Films with only CNMA (Fig. 4A and 4B) exhibited antimicrobial activity against both species. CNMA at $0.3 \%$ and $0.4 \%$ caused approximately 4.0 and 5.7 Log viable cell reductions, respectively, on Salmonella growth. When it comes to E. coli, CNMA decreased by 3.0 Log the number of viable cells at both concentrations of CNMA tested. The combination of CNMA and $\varphi 135$ phage reduced drastically the number of viable Salmonella present on the surfaces $(7.0 \mathrm{Log})$, revealing a facilitative effect (Table 5). The combination of these agents prevented Salmonella growth at a rate greater than the best of the agents alone but less than if the two were acting independently (Chaudhry et al., 2017). The combination of CNMA and EC4 phage demonstrated a synergistic effect against $E$. coli with approximately 7.0 Log reduction when the higher concentration of CNMA was used. Overall, these findings indicate that combinations of $\varphi 135$ and EC4 phages with CNMA have additive and synergic actions, respectively, in preventing bacterial growth on the surface of films. This mutually enhanced antimicrobial effect may be explained by their mechanisms of action. It has been reported that hydrophobic oil compounds such as CNMA interact with bacterial cell membranes, changing the lipid monolayer structure resulting in the leakage of phosphate and other essential cell components and a change in the membrane potential, ultimately causing the death of cells (Nowotarska et al., 2017). Phages act against bacteria by two mechanisms: after replication inside the cells with subsequent lysis ("lysis from within") or by adherence of a sufficiently high number of phage particles to a cell, causing its lysis through alteration of the membrane potential and/or the activity of cell wall degrading enzymes ("lysis from without") (Abedon, 2011). CNMA may be enhancing the phages action by altering the bacterial cell membranes and by this mean facilitating the introduction of phages genetic material into the cell (see Fig. 5). Alternatively, it may also be acting in simultaneous with phages on the cell membranes causing bacterial lysis through alteration of the membrane potential (Kon \& Rai, 2012).

The combination of CNMA and EC4 or $\varphi 135$ tested against the nonspecific hosts, displayed a similar antimicrobial activity to CNMA incorporated alone for the lower CNMA concentration tested. This was not observed, however, when a higher amount of CNMA was incorporated with EC4, as its presence compromised the antimicrobial activity of CNMA against the non-specific Salmonella host (Fig. 4A and B). It is known that natural antimicrobials, such as CNMA, modify the bacterial cell membrane structure by incorporation into the lipid monolayer (Nowotarska et al., 2017; Nowotarska, Nowotarski, Friedman, \& Situ, 2014; Wong, Grant, Friedman, Elliott, \& Situ, 2008). This incorporation forms aggregates of antimicrobial compounds and lipids, causing reduction of the packaging ability of the lipid molecules, increase of membrane fluidity and alteration of the dipole moment of the monolayer. The events described depend on the structure of the natural antimicrobial compound and the nature of the monolayer, but in general, the natural antimicrobials target and disturb the structures of phospholipids of bacterial cell membranes (Nowotarska et al., 2014). The presence of EC4 might be somehow blocking the entry pathway of CNMA but further studies are needed to corroborate this assumption.

The combination of both phages was investigated in the presence and absence of CNMA (Fig. 4C). In the absence of CNMA, the combination of both phages resulted, in terms of antimicrobial efficacy against $E$. coli, in a better effect than the one observed using EC4 or 

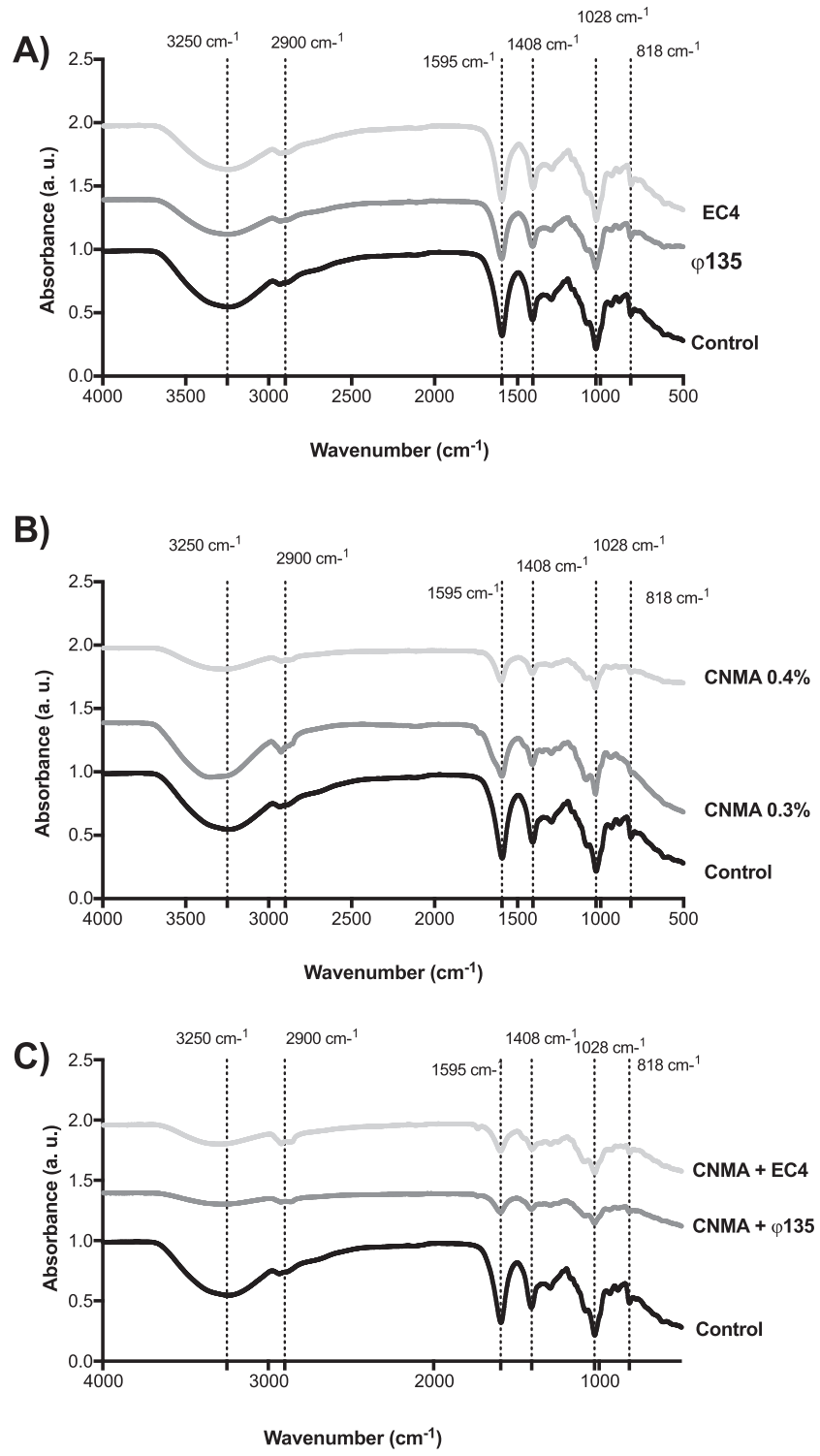

Fig. 4. FTIR spectra of sodium alginate films before and after entrapment of phages $\varphi 135$ or EC4 (A), CNMA (B) and CNMA in combination with phages (C).

$\varphi 135$ phages acting independently (synergism, Table 5). However, the antimicrobial activity of $\varphi 135$ phage was compromised by the presence of EC4 phage, resulting in a lower antimicrobial activity against Salmonella when both phages were added together, as compared to $\varphi 135$ alone $(p<0.05)$. This almost $2.5 \mathrm{Log}$ reduction in killing might be due to a non-specific adsorption of phage EC4 to Salmonella, blocking part of the surface receptors necessary for the adsorption to take place. This is however a mere hypothesis taking into account that phages are found attached to inert (Sillankorva, Neubauer, \& Azeredo, 2008b) and living surfaces (Van Belleghem, Dąbrowska, Vaneechoutte, Barr, \& Bollyky, 2019). For instance, it has been reported that diverse mucosal surfaces such as corals, fish, mice, and humans have higher numbers of phages in mucus than bacterial cells due to a weakly binding to mucin glycoproteins through protein domains that are displayed on the viral particle capsids (Barr et al., 2013; Nguyen-Kim et al., 2014, 2015). This phage adhering characteristic has been the focus of study and its adherence in a mucus model provided ubiquitous immunity to mucosal layers that was not host-derived, limiting bacterial adhesion, and thus providing an antimicrobial defense action (Barr et al., 2013).

The combination of both phages with CNMA enhanced their antimicrobial activity as evidenced by approximately 6 Log reductions
Table 5

Determination of possible occurrence of facilitation or synergism for combined antimicrobials entrapped in alginate films. The combinations where facilitation or synergism outcomes were obtained, are highlighted in grey. In these equations $\mathrm{C}$ refers to the cell density obtained in the control (sodium alginate films without antimicrobials) and S refers to the surviving cell density after being in contact with films entrapped with CNMA (at $0.3 \%$ and $0.4 \%$ ) and/or phages $\varphi 135$ and/or EC4.

\begin{tabular}{|c|c|c|}
\hline \multicolumn{3}{|l|}{ Facilitation } \\
\hline Combinations & S. Enteritidis & E. coli \\
\hline $\log \left(\mathrm{S}_{\mathrm{CNMA} \_0.3 \%+\mathrm{EC} 4}\right)-\log \left(\mathrm{S}_{\mathrm{CNMA} \_0.3 \%}\right)$ & 0.357 & 1.136 \\
\hline $\log \left(\mathrm{S}_{\mathrm{CNMA}_{-} 0.3 \%+\mathrm{EC} 4}\right)-\log \left(\mathrm{S}_{\mathrm{Ec} 4}\right)$ & -3.512 & -0.578 \\
\hline $\log \left(\mathrm{S}_{\mathrm{CNMA} \_.3 \%+\varphi 135}\right)-\log \left(\mathrm{S}_{\text {CNMA_0.3\% }}\right)$ & -3.316 & 0.743 \\
\hline $\log \left(\mathrm{S}_{\mathrm{CNMA}_{-} 0.3 \%+\varphi 135}\right)-\log \left(\mathrm{S}_{\varphi 135}\right)$ & -2.295 & -2.44 \\
\hline $\log \left(\mathrm{S}_{\text {CNMA_0.4\%+EC4 }}\right)-\log \left(\mathrm{S}_{\mathrm{CNMA} 0.4 \%}\right)$ & 3.103 & -3.835 \\
\hline $\log \left(\mathrm{S}_{\text {CNMA_0.4\%+EC4 }}\right)-\log \left(\mathrm{S}_{\mathrm{Ec} 4}\right)$ & -2.36 & -5.743 \\
\hline $\log \left(\mathrm{S}_{\text {CNMA_0.4\%+ } \% 135}\right)-\log \left(\mathrm{S}_{\text {CNMA_0.4\% }}\right)$ & -1.5534 & 0.5 \\
\hline $\log \left(\mathrm{S}_{\mathrm{CNMA}_{-} 0.4 \%+\varphi 135}\right)-\log \left(\mathrm{S}_{\varphi 135}\right)$ & -2.1264 & -2.877 \\
\hline $\log \left(\mathrm{S}_{\varphi 135}+\mathrm{EC} 4\right)-\log \left(\mathrm{S}_{\varphi 135}\right)$ & -2.391 & -0.621 \\
\hline $\log \left(\mathrm{S}_{\varphi 135+\mathrm{EC} 4}\right)-\log \left(\mathrm{S}_{\mathrm{Ec} 4}\right)$ & 2.499 & -2.09 \\
\hline $\log \left(\mathrm{S}_{\mathrm{CNMA} \_.3 \%+\varphi 135+\mathrm{EC} 4}\right)-\log \left(\mathrm{S}_{\mathrm{CNMA} \_0.3 \%}\right)$ & -4.228 & -4.6176 \\
\hline $\log \left(\mathrm{S}_{\mathrm{CNMA} 0.3 \%+\varphi 135+\mathrm{EC} 4}\right)-\log \left(\mathrm{S}_{\varphi 135+\mathrm{EC} 4}\right)$ & -2.75 & -3.5246 \\
\hline $\log \left(\mathrm{S}_{\mathrm{CNMA} \_0.4 \%+\varphi 135+\mathrm{EC} 4}\right)-\log \left(\mathrm{S}_{\mathrm{CNMA}_{-} 0.4 \%}\right)$ & -5.484 & -5.122 \\
\hline $\log \left(\mathrm{S}_{\mathrm{CNMA} 0.4 \%+\varphi 135+\mathrm{EC} 4}\right)-\log \left(\mathrm{S}_{\varphi 135+\mathrm{EC} 4}\right)$ & -2.412 & -3.835 \\
\hline \multicolumn{3}{|l|}{ Synergism } \\
\hline Combinations & S. Enteritidis & E. coli \\
\hline $\begin{array}{l}\log (\mathrm{C})-\log \left(\mathrm{S}_{\mathrm{CNMA} \_0.3 \%}\right)-\log \left(\mathrm{S}_{\mathrm{EC} 4}\right)+\log \\
\quad\left(\mathrm{S}_{\mathrm{CNMA} \_0.3 \%+\mathrm{EC} 4}\right)\end{array}$ & 0.59 & 2.535 \\
\hline $\begin{array}{l}\log (\mathrm{C})-\log \left(\mathrm{S}_{\mathrm{CNMA}_{-} 0.3 \%}\right)-\log \left(\mathrm{S}_{\varphi 135}\right)+\log \\
\quad\left(\mathrm{S}_{\text {CNMA_0.3\% }}+\varphi 135\right)\end{array}$ & 1.776 & 0.673 \\
\hline $\begin{array}{l}\log (\mathrm{C})-\log \left(\mathrm{S}_{\mathrm{CNMA}_{-} 0.4 \%}\right)-\log \left(\mathrm{S}_{\mathrm{EC} 4}\right)+\log \\
\quad\left(\mathrm{S}_{\left.\mathrm{CNMA}_{-} 0.4 \%+\mathrm{EC}_{4}\right)}\right.\end{array}$ & 3.305 & -2.436 \\
\hline $\begin{array}{l}\log (\mathrm{C})-\log \left(\mathrm{S}_{\mathrm{CNMA}_{-} 0.4 \%}\right)-\log \left(\mathrm{S}_{\varphi 135}\right)+\log \\
\quad\left(\mathrm{S}_{\text {CNMA_}} 0.4 \%+\varphi 135\right)\end{array}$ & 3.5386 & 0.43 \\
\hline $\log (C)-\log \left(S_{\varphi 135}\right)-\log \left(S_{E C 4}\right)+\log \left(S_{\varphi 135+E C 4}\right)$ & 2.701 & -0.691 \\
\hline $\begin{array}{l}\log (\mathrm{C})-\log \left(\mathrm{S}_{\varphi 135+\mathrm{EC} 4}\right)-\log \left(\mathrm{S}_{\mathrm{CNMA}_{-} .3 \%}\right)+\log \\
\quad\left(\mathrm{S}_{\mathrm{CNMA} \_0.3 \%+\varphi 135+\mathrm{EC} 4}\right)\end{array}$ & -0.157 & -1.5046 \\
\hline $\begin{array}{l}\log (\mathrm{C})-\log \left(\mathrm{S}_{\varphi 135}+\mathrm{EC} 4\right)-\log \left(\mathrm{S}_{\mathrm{CNMA}_{-} .4 \%}\right)+\log \\
\quad\left(\mathrm{S}_{\mathrm{CNMA} \_} 0.4 \%+\varphi 135+\mathrm{EC} 4\right)\end{array}$ & 0.181 & -1.815 \\
\hline
\end{tabular}

found against both species. Phages incorporation with CNMA at $0.4 \%$ ( $\mathrm{v} / \mathrm{v})$ comprised the best formulation, as it was able to completely prevent the growth of both species in these films. Combination of both phages with CNMA resulted in a synergic antimicrobial effect against $E$. coli and a facilitative effect against Salmonella (Table 5). The advantages of this strategy include the reduction of CNMA concentration, which can minimize the negative organoleptic effects associated to this compound. Furthermore, strategies based on antimicrobial combinations prevent the emergence of resistance (Worthington \& Melander, 2013).

\section{Conclusions}

This work shows that a combination of CNMA emulsions with a cocktail of phages can be successfully incorporated in sodium alginate based films. Phages entrapment did not compromise their viability as well as their combination with CNMA. CNMA emulsions became more heterogeneous after increasing CNMA concentration with subsequent increase on CNMA loaded inside the films. In general, phages incorporation alone did not influence films parameters such as morphology, thickness, MC, WVP and SW. CNMA incorporation, on the other hand, increased films' roughness, thickness and swelling ability. Combination of both phages (EC4 and $\varphi 135$ ) with CNMA enhanced the antimicrobial activity of compounds alone against $E$. coli and had an additive effect against Salmonella. Overall, this study highlights the great potential of this strategy to be further explored in food packaging systems to fight foodborne illness. 
A)

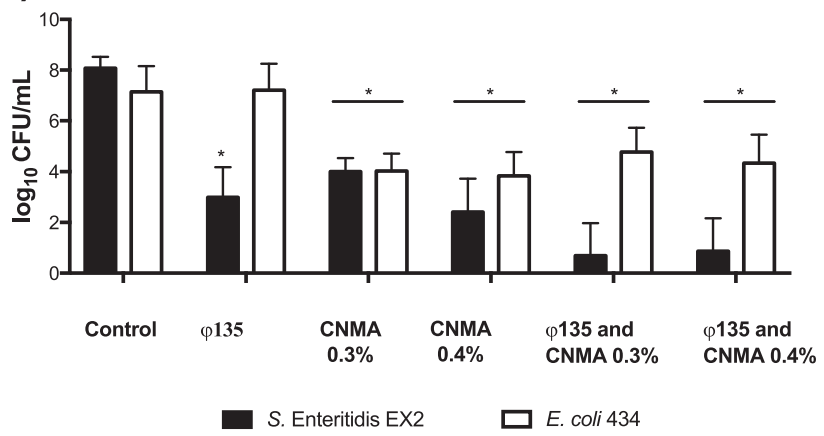

B)

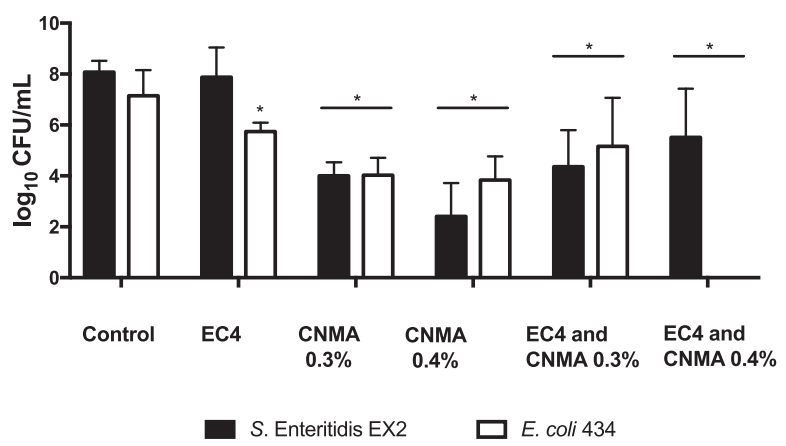

C)

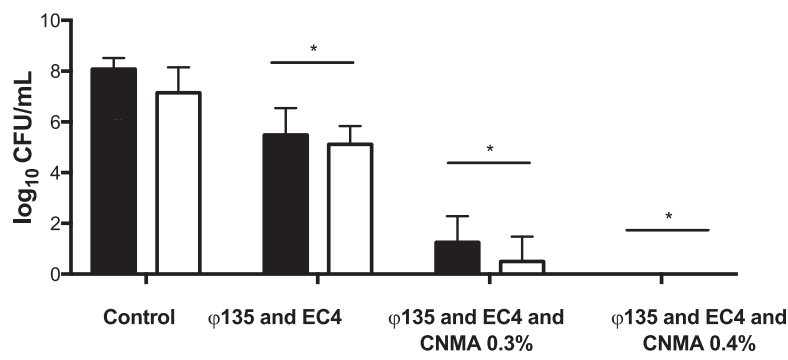

S. Enteritidis EX2 $\square$ E. coli 434

Fig. 5. Antimicrobial activity of $\varphi 135$ phage incorporated in sodium alginatebased films with and without CNMA (A), EC4 phage incorporated in sodium alginate- based films with and without CNMA (B) and both phages incorporated in sodium alginate- based films with and without CNMA (C) over a period of $24 \mathrm{~h}$ when in contact with $S$. Enteritidis EX2 and E. coli 434. Sodium alginatebased films without incorporated phage(s) or CNMA were used as control. * indicates significant differences $(p<0.05)$ between the two bacterial controls in an alginate film and the prepared films.

\section{Declaration of Competing Interest}

The authors declared that there is no conflict of interest.

\section{Acknowledgments}

This project has received funding from the European Union's Horizon 2020 research and innovation programme under grant agreement No 713640. This study was also supported by the Portuguese Foundation for Science and Technology (FCT) under the scope of the strategic funding of UID/BIO/04469/2019 unit and BioTecNorte operation (NORTE-01-0145-FEDER-000004) funded by the European Regional Development Fund under the scope of Norte2020 - Programa Operacional Regional do Norte.

\section{References}

Abdelsattar, A. S., Abdelrahman, F., Dawoud, A., Connerton, I. F., \& El-Shibiny, A. (2019). Encapsulation of $E$. coli phage ZCEC5 in chitosan-alginate beads as a delivery system in phage therapy. AMB Express. https://doi.org/10.1186/s13568-019-0810-9.

Abedon, S. T. (2011). Lysis from without. Bacteriophage. https://doi.org/10.4161/bact.1. 1.13980 .

Adams, M. H. (1959). Bacteriophages. (Interscience Publishers, Ed.). New York.

Akhter, R., Masoodi, F. A., Wani, T. A., \& Rather, S. A. (2019). Functional characterization of biopolymer based composite film: Incorporation of natural essential oils and antimicrobial agents. International Journal of Biological Macromolecules. https://doi.org/ 10.1016/j.ijbiomac.2019.06.214.

Alves, D., Marques, A., Milho, C., Costa, M. J., Pastrana, L. M., Cerqueira, M. A., \& Sillankorva, S. M. (2018). Bacteriophage $\phi I B B-P F 7 A$ loaded on sodium alginate-based films to prevent microbial meat spoilage. International Journal of Food Microbiology, 291(September 2018), 121-127. https://doi.org/10.1016/j.ijfoodmicro.2018.11. 026.

Amarillas, L., Lightbourn-Rojas, L., Angulo-Gaxiola, A. K., Basilio Heredia, J., GonzálezRobles, A., \& León-Félix, J. (2018). The antibacterial effect of chitosan-based edible coating incorporated with a lytic bacteriophage against Escherichia coli 0157:H7 on the surface of tomatoes. Journal of Food Safety. https://doi.org/10.1111/jfs.12571.

Bakry, A. M., Abbas, S., Ali, B., Majeed, H., Abouelwafa, M. Y., Mousa, A., \& Liang, L. (2016). Microencapsulation of Oils: A Comprehensive Review of Benefits,

Techniques, and Applications. Comprehensive Reviews in Food Science and Food Safety. https://doi.org/10.1111/1541-4337.12179.

Barr, J., Auro, R., Furlan, M., Whiteson, K. L., Auro, R., Barr, J. J., ... Rohwer, F. (2013). Bacteriophage adhering to mucus provide a non-host-derived immunity. Proc Natl Acad Sci. https://doi.org/10.1073/pnas.1305923110.

Bhavaniramya, S., Vishnupriya, S., Al-Aboody, M. S., Vijayakumar, R., \& Baskaran, D. (2019). Role of essential oils in food safety: Antimicrobial and antioxidant applications. Grain \& Oil Science and Technology. https://doi.org/10.1016/j.gaost.2019.03. 001.

Bull, J. J., \& Gill, J. J. (2014). The habits of highly effective phages: Population dynamics as a framework for identifying therapeutic phages. Frontiers in Microbiology. https:// doi.org/10.3389/fmicb.2014.00618.

Burt, S. A., Adolfse, S. J. M., Ahad, D. S. A., Tersteeg-Zijderveld, M. H. G., JongeriusGortemaker, B. G. M., Post, J. A., ... Santos, R. R. (2016). Cinnamaldehyde, Carvacrol and Organic Acids Affect Gene Expression of Selected Oxidative Stress and Inflammation Markers in IPEC-J2 Cells Exposed to Salmonella typhimurium. Phytotherapy Research. https://doi.org/10.1002/ptr.5705.

Cao, N., Fu, Y., \& He, J. (2007). Preparation and physical properties of soy protein isolate and gelatin composite films. Food Hydrocolloids. https://doi.org/10.1016/j.foodhyd. 2006.09.001.

Casariego, A., Souza, B. W. S., Cerqueira, M. A., Teixeira, J. A., Cruz, L., Díaz, R., \& Vicente, A. A. (2009). Chitosan/clay films' properties as affected by biopolymer and clay micro/nanoparticles' concentrations. Food Hydrocolloids, 23(7), 1895-1902. https://doi.org/10.1016/j.foodhyd.2009.02.007.

Centers for Disease Control and Prevention (CDC). (2018). Salmonella - information for healthcare professionals and laboratories. Obtido 20 de Dezembro de 2018, de https://www.cdc.gov/salmonella/general/technical.html.

Cerqueira, M. A., Fabra, M. J., Castro-Mayorga, J. L., Bourbon, A. I., Pastrana, L. M., Vicente, A. A., \& Lagaron, J. M. (2016). Use of Electrospinning to Develop Antimicrobial Biodegradable Multilayer Systems: Encapsulation of Cinnamaldehyde and Their Physicochemical Characterization. Food and Bioprocess Technology. https:// doi.org/10.1007/s11947-016-1772-4.

Chaudhry, W. N., Concepcion-Acevedo, J., Park, T., Andleeb, S., Bull, J. J., \& Levin, B. R. (2017). Synergy and order effects of antibiotics and phages in killing pseudomonas aeruginosa biofilms. PLoS One. https://doi.org/10.1371/journal.pone.0168615.

Cinteza, L., Scomoroscenco, C., Voicu, S., Nistor, C., Nitu, S., Trica, B., ... Petcu, C. (2018). Chitosan-stabilized Ag nanoparticles with superior biocompatibility and their synergistic antibacterial effect in mixtures with essential oils. Nanomaterials. https:// doi.org/10.3390/nano8100826.

CLSI (2003). Methods for dilution antimicrobial susceptibility tests for bacteria that grow aerobically.

Colom, J., Cano-Sarabia, M., Otero, J., Aríñez-Soriano, J., Cortés, P., Maspoch, D., \& Llagostera, M. (2017). Microencapsulation with alginate/CaCO 3: A strategy for improved phage therapy. Scientific Reports. https://doi.org/10.1038/srep41441.

Costa, M. J., Marques, A. M., Pastrana, L. M., Teixeira, J. A., Sillankorva, S. M., \& Cerqueira, M. A. (2018). Physicochemical properties of alginate-based films: Effect of ionic crosslinking and mannuronic and guluronic acid ratio. Food Hydrocolloids. https://doi.org/10.1016/j.foodhyd.2018.03.014.

de Oliveira Elias, S., Noronha, T. B., \& Tondo, E. C. (2019). Salmonella spp. and Escherichia coli 0157:H7 prevalence and levels on lettuce: A systematic review and meta-analysis. Food Microbiology.. https://doi.org/10.1016/j.fm.2019.05.001.

Du, W. X., Olsen, C. W., Avena-Bustillos, R. J., McHugh, T. H., Levin, C. E., Mandrell, R., \& Friedman, M. (2009). Antibacterial effects of allspice, garlic, and oregano essential oils in tomato films determined by overlay and vapor-phase methods. Journal of Food Science. https://doi.org/10.1111/j.1750-3841.2009.01289.x.

El Fawal, G. F., Omer, A. M., \& Tamer, T. M. (2019). Evaluation of antimicrobial and antioxidant activities for cellulose acetate films incorporated with Rosemary and Aloe Vera essential oils. Journal of Food Science and Technology. https://doi.org/10.1007/ s13197-019-03642-8.

Fabra, M. J., Talens, P., \& Chiralt, A. (2010). Water sorption isotherms and phase transitions of sodium caseinate-lipid films as affected by lipid interactions. Food Hydrocolloids. https://doi.org/10.1016/j.foodhyd.2009.11.004. 
Fertah, M., Belfkira, A., Dahmane, E. M., Taourirte, M., \& Brouillette, F. (2017). Extraction and characterization of sodium alginate from Moroccan Laminaria digitata brown seaweed. Arabian Journal of Chemistry. https://doi.org/10.1016/j.arabjc. 2014. 05.003.

Frank, K., Garcia, C. V., Shin, G. H., \& Kim, J. T. (2018). Alginate biocomposite films incorporated with cinnamon essential oil nanoemulsions: Physical, mechanical, and antibacterial properties. International Journal of Polymer Science. https://doi.org/10. $1155 / 2018 / 1519407$.

Galié, S., García-Gutiérrez, C., Miguélez, E. M., Villar, C. J., \& Lombó, F. (2018). Biofilms in the food industry: Health aspects and control methods. Frontiers in Microbiology. https://doi.org/10.3389/fmicb.2018.00898.

Ghosh, A., Ricke, S. C., Almeida, G., \& Gibson, K. E. (2016). Combined application of essential oil compounds and bacteriophage to inhibit growth of Staphylococcus aureus In Vitro. Current Microbiology. https://doi.org/10.1007/s00284-015-0968-6.

Guillard, V., Broyart, B., Bonazzi, C., Guilbert, S., \& Gontard, N. (2003). Preventing moisture transfer in a composite food using edible films: Experimental and mathematical study. Journal of Food Science, 68(7), 2267-2277. https://doi.org/10.1111/j. 1365-2621.2003.tb05758.x.

Hadian, M., Rajaei, A., Mohsenifar, A., \& Tabatabaei, M. (2017). Encapsulation of Rosmarinus officinalis essential oils in chitosan-benzoic acid nanogel with enhanced antibacterial activity in beef cutlet against Salmonella typhimurium during refrigerated storage. LWT - Food Science and Technology. https://doi.org/10.1016/j.lwt. 2017.05.075.

Hashemi, S. M. B., \& Mousavi Khaneghah, A. (2017). Characterization of novel basil-seed gum active edible films and coatings containing oregano essential oil. Progress in Organic Coatings. https://doi.org/10.1016/j.porgcoat.2017.04.041.

Hoelzer, K., Switt, M. I. A., Wiedmann, M., \& Boor, K. J. (2018). Emerging needs and opportunities in foodborne disease detection and prevention: From tools to people. Food Microbiology. https://doi.org/10.1016/j.fm.2017.07.006.

Huang, K., \& Nitin, N. (2019). Edible bacteriophage based antimicrobial coating on fish feed for enhanced treatment of bacterial infections in aquaculture industry. Aquaculture. https://doi.org/10.1016/j.aquaculture.2018.12.026.

Hyldgaard, M., Mygind, T., \& Meyer, R. L. (2012). Essential oils in food preservation: Mode of action, synergies, and interactions with food matrix components. Frontiers in Microbiology. https://doi.org/10.3389/fmicb.2012.00012.

Japanese Standards Association. (2000). Antimicrobial products Test for antimicrobial activity and efficacy, Japanese Industrial Standard JIS Z 2801,. Reference number: JIS Z 2801: 2000 (E), First English edition published in 2001, 2000, 1-14.

Jorge, P., Magalhães, A. P., Grainha, T., Alves, D., Sousa, A. M., Lopes, S. P., \& Pereira, M. O. (2019). Antimicrobial resistance three ways: Healthcare crisis, major concepts and the relevance of biofilms. FEMS Microbiology Ecology. https://doi.org/10.1093/ femsec/fiz115.

Khaneghah, A., Hashemi, S. M. B., \& Limbo, S. (2018). Antimicrobial agents and packaging systems in antimicrobial active food packaging: An overview of approaches and interactions. Food and Bioproducts Processing. https://doi.org/10.1016/ j.fbp. 2018.05.001.

Kon, K. V., \& Rai, M. K. (2012). Plant essential oils and their constituents in coping with multidrug-resistant bacteria. Expert Review of Anti-Infective Therapy. https://doi.org/ 10.1586/eri.12.57.

Lara, V. M., Carregaro, A. B., Santurio, D. F., de Sá, M. F., Santurio, J. M., \& Alves, S. H. (2016). Antimicrobial Susceptibility of Escherichia coli Strains Isolated from Alouatta spp. Feces to Essential Oils. Evidence-Based Complementary and Alternative Medicine. https://doi.org/10.1155/2016/1643762.

Lawrie, G., Keen, I., Drew, B., Chandler-Temple, A., Rintoul, L., Fredericks, P., \& Grøndahl, L. (2007). Interactions between alginate and chitosan biopolymers characterized using FTIR and XPS. Biomacromolecules. https://doi.org/10.1021/ bm070014y.

Lin, D. M., Koskella, B., \& Lin, H. C. (2017). Phage therapy: An alternative to antibiotics in the age of multi-drug resistance. World Journal of Gastrointestinal Pharmacology and Therapeutics. https://doi.org/10.4292/wjgpt.v8.i3.162.

Malik, D. J., Sokolov, I. J., Vinner, G. K., Mancuso, F., Cinquerrui, S., Vladisavljevic, G. T., ... Kirpichnikova, A. (2017). Formulation, stabilisation and encapsulation of bacteriophage for phage therapy. Advances in Colloid and Interface Science, 249, 100-133. https://doi.org/10.1016/J.CIS.2017.05.014.

McLinden, T., Sargeant, J. M., Thomas, M. K., Papadopoulos, A., \& Fazil, A. (2014). Component costs of foodborne illness: A scoping review. BMC Public Health. https:// doi.org/10.1186/1471-2458-14-509.

Milho, C. (2019). Control of Salmonella Enteritidis biofilms present on different food contact surfaces using bacteriophages. University of Minho.

Milho, C., Silva, M. D., Melo, L., Santos, S., Azeredo, J., \& Sillankorva, S. (2018). Control of Salmonella Enteritidis on food contact surfaces with bacteriophage PVP-SE2. Biofouling. https://doi.org/10.1080/08927014.2018.1501475.

Moghtader, F., Eğri, S., \& Piskin, E. (2017). Phages in modified alginate beads. Artificial Cells, Nanomedicine and Biotechnology.. https://doi.org/10.3109/21691401.2016. 1153485.

Moye, Z. D., Woolston, J., \& Sulakvelidze, A. (2018). Bacteriophage applications for food production and processing. Viruses. https://doi.org/10.3390/v10040205.

Nguyen-Kim, H., Bettarel, Y., Bouvier, T., Bouvier, C., Doan-Nhu, H., Nguyen-Ngoc, L., ... Brune, J. (2015). Coral Mucus Is a Hot Spot for Viral Infections. Applied and Environmental Microbiology. https://doi.org/10.1128/aem.00542-15.

Nguyen-Kim, H., Bouvier, T., Bouvier, C., Doan-Nhu, H., Nguyen-Ngoc, L., RochelleNewall, E., ... Bettarel, Y. (2014). High occurrence of viruses in the mucus layer of scleractinian corals. Environmental Microbiology Reports. https://doi.org/10.1111/ 1758-2229.12185.

Nowotarska, S., Nowotarski, K., Grant, I., Elliott, C., Friedman, M., \& Situ, C. (2017). Mechanisms of Antimicrobial Action of Cinnamon and Oregano Oils,
Cinnamaldehyde, Carvacrol, 2,5-Dihydroxybenzaldehyde, and 2-Hydroxy-5 Methoxybenzaldehyde against Mycobacterium avium subsp. paratuberculosis (Map). Foods. https://doi.org/10.3390/foods6090072.

Nowotarska, S. W., Nowotarski, K. J., Friedman, M., \& Situ, C. (2014). Effect of structure on the interactions between five natural antimicrobial compounds and phospholipids of bacterial cell membrane on model monolayers. Molecules. https://doi.org/10. 3390/molecules19067497.

Ocampo, P. S., Lázár, V., Papp, B., Arnoldini, M., Zur Wiesch, P. A., Busa-Fekete, R., ... Bonhoeffer, S. (2014). Antagonism between bacteriostatic and bactericidal antibiotics is prevalent. Antimicrobial Agents and Chemotherapy. https://doi.org/10.1128/AAC. 02463-14.

Otero, J., García-Rodríguez, A., Cano-Sarabia, M., Maspoch, D., Marcos, R., Cortés, P., \& Llagostera, M. (2019). Biodistribution of liposome-encapsulated bacteriophages and their transcytosis during oral phage therapy. Frontiers in Microbiology. https://doi. org/10.3389/fmicb.2019.00689.

Otoni, C. G., Avena-Bustillos, R. J., Olsen, C. W., Bilbao-Sáinz, C., \& McHugh, T. H. (2016). Mechanical and water barrier properties of isolated soy protein composite edible films as affected by carvacrol and cinnamaldehyde micro and nanoemulsions. Food Hydrocolloids. https://doi.org/10.1016/j.foodhyd.2016.01.012.

Pei, R. S., Zhou, F., Ji, B. P., \& Xu, J. (2009). Evaluation of combined antibacterial effects of eugenol, cinnamaldehyde, thymol, and carvacrol against $E$. coli with an improved method. Journal of Food Science. https://doi.org/10.1111/j.1750-3841.2009. 01287.x.

Perdones, Á., Vargas, M., Atarés, L., \& Chiralt, A. (2014). Physical, antioxidant and antimicrobial properties of chitosan-cinnamon leaf oil films as affected by oleic acid. Food Hydrocolloids. https://doi.org/10.1016/j.foodhyd.2013.10.003.

Pereira, R., Tojeira, A., Vaz, D. C., Mendes, A., \& Bártolo, P. (2011). Preparation and characterization of films based on alginate and aloe vera. International Journal of Polymer Analysis and Characterization. https://doi.org/10.1080/1023666X.2011. 599923.

Petsong, K., Benjakul, S., \& Vongkamjan, K. (2019). Evaluation of storage conditions and efficiency of a novel microencapsulated Salmonella phage cocktail for controlling S. enteritidis and S. typhimurium in-vitro and in fresh foods. Food Microbiology.. https:// doi.org/10.1016/j.fm.2019.05.008.

Rao, J., \& McClements, D. J. (2012). Food-grade microemulsions and nanoemulsions: Role of oil phase composition on formation and stability. Food Hydrocolloids. https:// doi.org/10.1016/j.foodhyd.2012.04.008.

Ribeiro-Santos, R., Andrade, M., \& Sanches-Silva, A. (2017). Application of encapsulated essential oils as antimicrobial agents in food packaging. Current Opinion in Food Science. https://doi.org/10.1016/j.cofs.2017.01.012.

Sambrook, J., \& Russel, D. (2001). Molecular Cloning: A Laboratory Manual. (Cold Spring Harbor Laboratory Press, Ed.) (4th Editio). New York: Cold Spring Harbor.

Scandorieiro, S., de Camargo, L. C., Lancheros, C. A. C., Yamada-Ogatta, S. F., Nakamura, C. V., de Oliveira, A. G., ... Kobayashi, R. K. T. (2016). Synergistic and additive effect of oregano essential oil and biological silver nanoparticles against multidrug-resistant bacterial strains. Frontiers in Microbiology. https://doi.org/10.3389/fmicb.2016. 00760.

Shi, H., \& Tarabara, V. V. (2018). Charge, size distribution and hydrophobicity of viruses: Effect of propagation and purification methods. Journal of Virological Methods. https://doi.org/10.1016/j.jviromet.2018.02.008.

Sillankorva, Neubauer, P., \& Azeredo, J. (2008). Isolation and characterization of a T7like lytic phage for Pseudomonas fluorescens. BMC Biotechnology, 8, 1-11. https:// doi.org/10.1186/1472-6750-8-80.

Sillankorva, Oliveira, H., \& Azeredo, J. (2012). Bacteriophages and their role in food safety. International Journal of Microbiology. https://doi.org/10.1155/2012/863945.

Sillankorva, Pleteneva, E., Shaburova, O., Santos, S., Carvalho, C., Azeredo, J., \& Krylov, V. (2010). Salmonella Enteritidis bacteriophage candidates for phage therapy of poultry. Journal of Applied Microbiology, 108(4), 1175-1186. https://doi.org/10. 1111/j.1365-2672.2009.04549.x.

Sillankorva, S., Neubauer, P., \& Azeredo, J. (2008). Pseudomonas fluorescens biofilms subjected to phage philBB-PF7A. BMC Biotechnology. https://doi.org/10.1186/1472 6750-8-79.

Simionato, I., Domingues, F. C., Nerín, C., \& Silva, F. (2019). Encapsulation of cinnamon oil in cyclodextrin nanosponges and their potential use for antimicrobial food packaging. Food and Chemical Toxicology. https://doi.org/10.1016/j.fct.2019. 110647.

Solarte, A. L., Astorga, R. J., de Aguiar, F. C., De Frutos, C., Barrero-Domínguez, B., \& Huerta, B. (2018). Susceptibility distribution to essential oils of Salmonella enterica strains involved in animal and public health and comparison of the Typhimurium and Enteritidis serotypes. Journal of Medicinal Food. https://doi.org/10.1089/jmf.2017. 0103.

Tomat, D., Soazo, M., Verdini, R., Casabonne, C., Aquili, V., Balagué, C., \& Quiberoni, A. (2019). Evaluation of an WPC edible film added with a cocktail of six lytic phages against foodborne pathogens such as enteropathogenic and Shigatoxigenic Escherichia coli. LWT. https://doi.org/10.1016/j.lwt.2019.108316.

Van Belleghem, J. D., Dąbrowska, K., Vaneechoutte, M., Barr, J. J., \& Bollyky, P. L. (2019). Interactions between bacteriophage, bacteria, and the mammalian immune system. Viruses. https://doi.org/10.3390/v11010010.

Viazis, S., Akhtar, M., Feirtag, J., \& Diez-Gonzalez, F. (2011). Reduction of Escherichia coli $0157: H 7$ viability on leafy green vegetables by treatment with a bacteriophage mixture and trans-cinnamaldehyde. Food Microbiology. https://doi.org/10.1016/j.fm. 2010.09.009.

Vonasek, E. L., Choi, A. H., Sanchez, J., \& Nitin, N. (2018). Incorporating Phage Therapy into WPI Dip Coatings for Applications on Fresh Whole and Cut Fruit and Vegetable Surfaces. Journal of Food Science. https://doi.org/10.1111/1750-3841.14188.

Voo, W. P., Lee, B. B., Idris, A., Islam, A., Tey, B. T., \& Chan, E. S. (2015). Production of 
ultra-high concentration calcium alginate beads with prolonged dissolution profile. RSC Advances. https://doi.org/10.1039/c5ra03862f.

Wong, S. Y. Y., Grant, I. R., Friedman, M., Elliott, C. T., \& Situ, C. (2008). Antibacterial activities of naturally occurring compounds against Mycobacterium avium subsp. paratuberculosis. Applied and Environmental Microbiology.. https://doi.org/10.1128/ AEM.00981-08.

Worthington, R. J., \& Melander, C. (2013). Combination approaches to combat multidrug-resistant bacteria. Trends in Biotechnology. https://doi.org/10.1016/j.tibtech.
2012.12.006.

Wu, J., Sun, X., Guo, X., Ge, S., \& Zhang, Q. (2017). Physicochemical properties, antimicrobial activity and oil release of fish gelatin films incorporated with cinnamon essential oil. Aquaculture and Fisheries. https://doi.org/10.1016/j.aaf.2017.06.004. Yildirim, S., Röcker, B., Pettersen, M. K., Nilsen-Nygaard, J., Ayhan, Z., Rutkaite, R., ...

Coma, V. (2018). Active packaging applications for food. Comprehensive Reviews in Food Science and Food Safety. https://doi.org/10.1111/1541-4337.12322. 